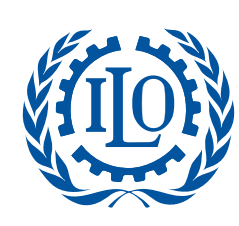

International Labour

Organization

\title{
Coop ${ }^{\text {AFRlCA }}$ Working Paper No.1
}

\section{Reinventing the wheel? African cooperatives in a liberalized economic environment}

Fredrick O. Wanyama, Patrick Develtere and Ignace Pollet

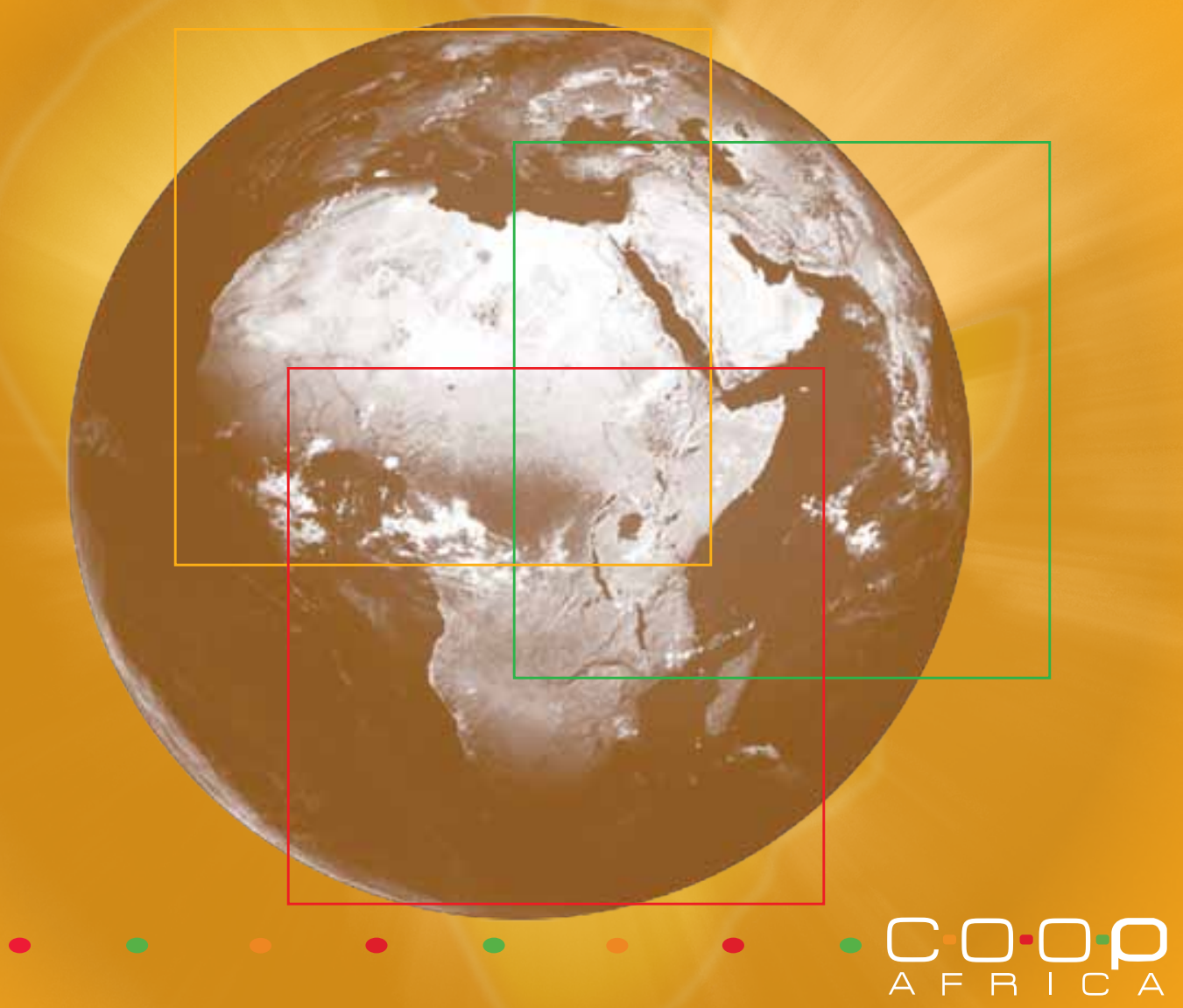




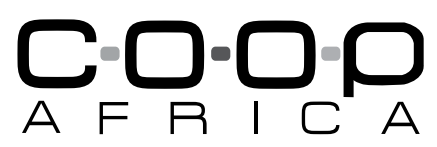

The Cooperative Facility for Africa (Coop ${ }^{\mathrm{AFRICA}}$ ) is a regional technical cooperation programme of the ILO contributing to the achievement of the Millennium Development Goals and the promotion of decent work in Africa by promoting self-help initiatives, mutual assistance in communities and cross border exchanges through the cooperative approach.

Coop ${ }^{\text {AFRICA }}$ contributes to improving the governance, efficiency and performance of primary cooperatives, other social economy organizations and their higher level structures in order to strengthen their capacity to access markets, create jobs, generate income, reduce poverty, provide social protection and give their members a voice and representation in society.

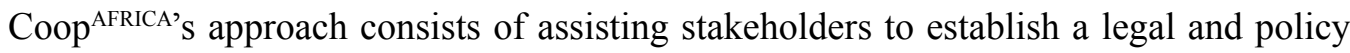
environment conducive to the development of cooperatives; providing support services through identified 'Centres of competence'; promoting effective co-coordinating structures (e.g., unions and federations) and establishing and maintaining challenge fund mechanisms, for 'services', 'innovation', and 'training'. These funds are accessible through a competitive demand-driven mechanism and a transparent selection of the best proposals.

Coop ${ }^{\text {AFRICA }}$ and its network of 'Centres of competence' provide different types of services: policy and legal advice; studies and publications; training and education; support to field projects; development or adaptation of didactical and methodological material; networking; advocacy; and promotion of innovative cooperative ventures among others.

Coop ${ }^{\text {AFRICA }}$ is located in the ILO Office for Kenya, Somalia, Tanzania and Uganda, and is part of the Cooperative Programme (EMP/COOP) of the Job Creation and Enterprise Development Department of the ILO. The programme works in partnership with the International Cooperative Alliance (ICA), the UK Cooperative College, the Committee for the Promotion and Advancement of Cooperatives (COPAC), the International Trade Union Confederation (ITUC-Africa), the International Organisation of Employers (IOE) and the African Union Secretariat. Coop ${ }^{\mathrm{AFRICA}}$ is a multi-donors programme primarily supported by the UK Department for International Development (DfID). It also receives support from the Swedish International Development Cooperation Agency (Sida), the Government of Finland, the Arab Gulf Programme for United Nations Development Organizations (AGFUND) and the German Cooperative and Raiffeisen Confederation (DGRV).

ILO Office for Kenya, Somalia,

Tanzania and Uganda

Coop $^{\text {Arrica }}$

Kazi House, Maktaba Street

P.O. Box 9212

Dar es Salaam

United Republic of Tanzania

Tel: +255.22 .2196700$

Fax: +255.22.2122597

E-mail: coopafrica@ilo.org

www.ilo.org/coopafrica
International Labour Office

Cooperative Programme (EMP/COOP)

4 , route des Morillons

1211 Geneva 22

Switzerland

Tel: +41.22 .7997445$

Fax: +41.22.7998572

E-mail: coop@,ilo.org

www.ilo.org/coop 
International

Labour

Organization

Coop ${ }^{\text {AFRICA }}$ Working Paper No.1

\section{Reinventing the wheel? African cooperatives in a liberalized economic environment}

Fredrick O. Wanyama, Patrick Develtere and Ignace Pollet

\section{9}

*This article was published in the Annals of Public and Cooperative Economics, Volume 80 Issue 3 (September 2009) 
Publications of the International Labour Office enjoy copyright under Protocol 2 of the Universal Copyright Convention. Nevertheless, short excerpts from them may be reproduced without authorization, on condition that the source is indicated. For rights of reproduction or translation, application should be made to ILO Publications (Rights and Permissions), International Labour Office, CH-1211 Geneva 22, Switzerland, or by email: pubdroit@ilo.org The International Labour Office welcomes such applications.

Libraries, institutions and other users registered with reproduction rights organizations may make copies in accordance with the licences issued to them for this purpose. Visit www.ifrro.org to find the reproduction rights organization in your country.

ILO Cataloguing in Publication Data

Wanyama, Fredrick O.; Develtere, Patrick; Pollet, Ignace

Reinventing the wheel? African cooperatives in a liberalized economic environment / by Fredrick O. Wanyama, Patrick Develtere and Ignace Pollet ; International Labour Office. - Dar es Salaam: ILO, 2009

1 v. (CoopAFRICA working paper ; no.1)

ISBN: $9789221225560 ; 9789221225577$ (web pdf)

International Labour Office

cooperative / cooperative development / economic reform / Africa south of Sahara 03.05

The designations employed in ILO publications, which are in conformity with United Nations practice, and the presentation of material therein do not imply the expression of any opinion whatsoever on the part of the International Labour Office concerning the legal status of any country, area or territory or of its authorities, or concerning the delimitation of its frontiers.

The responsibility for opinions expressed in signed articles, studies and other contributions rests solely with their authors, and publication does not constitute an endorsement by the International Labour Office of the opinions expressed in them.

Reference to names of firms and commercial products and processes does not imply their endorsement by the International Labour Office, and any failure to mention a particular firm, commercial product or process is not a sign of disapproval.

ILO publications and electronic products can be obtained through major booksellers or ILO local offices in many countries, or direct from ILO Publications, International Labour Office, CH-1211 Geneva 22, Switzerland. Catalogues or lists of new publications are available free of charge from the above address, or by email: pubvente@ilo.org

Visit our website: www.ilo.org/publns

Printed in Tanzania 


\section{Table of contents}

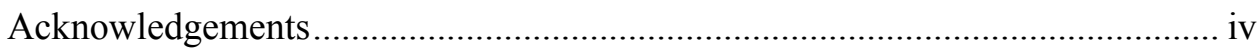

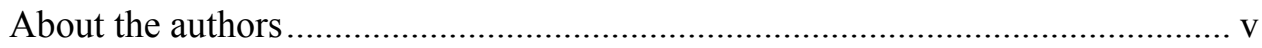

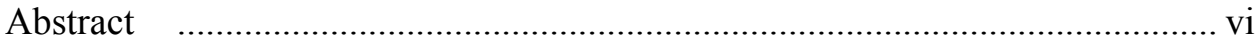

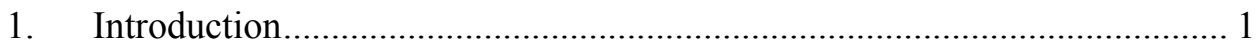

2. The origin and arrest of cooperatives in Africa ......................................... 3

2.1 The origin of cooperatives in Africa: an overview ............................. 3

2.2 African independence and the arrest of cooperatives ........................ 4

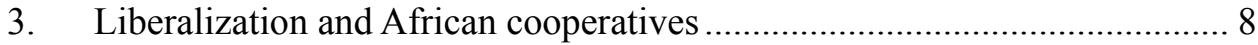

3.1 Wither away African cooperatives? ................................................ 10

3.2 The structural organization of cooperatives ......................................11

3.3 The diversification of cooperative ventures................................... 14

3.4 Sifting the grain from the chaff: the performance of cooperatives.... 16

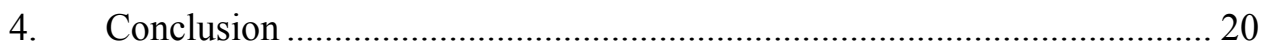

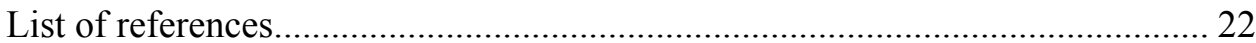




\section{Acknowledgements}

The purpose of the said study was to obtain qualitative insights into the strengths and weaknesses of the cooperative movement in the countries with a view to assessing the real and potential impact of cooperatives on reduction of poverty through creation of employment; generation of economic activities; enhancement of social protection; and improvement of the voice and representation of vulnerable groups in society. The researchers, one in each of the eleven countries, first of all used qualitative rapid assessment methodology to collect data at the national level using semi-structured interviews with key informants in the cooperative sector. This was followed by in-depth interviews with leaders and members in selected cooperative societies at the local level with a view to generating case studies to illuminate on the findings from the national level. The eleven countries are Ethiopia, Egypt, Kenya, Uganda, Rwanda, South Africa, Nigeria, Ghana, Niger, Senegal and Cape Verde. The overall findings of this study have been published as P. Develtere, I. Pollet and F. Wanyama, eds, Cooperating out of Poverty: the Renaissance of the African Cooperative Movement, Geneva, ILO, 2008.

This publication has benefited from many fruitful discussions with stakeholders from the cooperative movement, ILO constituents, as well as Coop ${ }^{\text {AFricA }}$ and EMP/COOP staff members. In particular, the Authors acknowledge comments, suggestions and other inputs provided by Emma Allen, Elizabeth Mwakalinga and Philippe Vanhuynegem. Coop ${ }^{\text {AFRICA }}$ gratefully acknowledges the Annals of Public and Cooperative Economics, who also published this paper as an article in their journal (Volume 80, Issue 3 - September 2009). 


\begin{abstract}
About the authors
Patrick Develtere holds a PhD from the Katholieke University of Leuven, Belgium. He has been studying cooperatives and other civil society organizations in Europe, Africa, Asia and Latin America for more than 20 years. He is the director of the Research Group on Sustainable Development and Development Cooperation as well as of the Research Group on Civil Society and Social Economy of the Higher Institute for Labour Studies (HIVA) at the Katholieke University of Leuven. He has published several books and articles on cooperatives, the social economy and development.

Ignace Pollet is a senior researcher of the Higher Institute for Labour Studies at the Katholieke University of Leuven. As an organization specialist, he has a track record in research on different types of popular organizations as well as enterprises in both Belgium and developing countries.

Fredrick O. Wanyama holds a PhD in Political Science from Maseno University, Kenya and is a Senior Lecturer in the School of Development and Strategic Studies at the same university. Specializing in local organizations and politics in the African development process, he has contributed many chapters and articles to academic edited books and refereed journals. He is a recipient of fellowships from distinguished bodies like CODESRIA, DAAD, the Five College African Scholars Program, Amherst, Massachusetts, USA and HIVA at the Katholieke University of Leuven, Belgium.
\end{abstract}




\begin{abstract}
Cooperative development in Africa can be said to have traversed two main eras: the era of state control and that of liberalization. The first era lasted up to the early 1990s and saw the origin and substantial growth of cooperatives on the continent. During that period, different models of cooperative development were introduced on the continent. We distinguish a unified cooperative model, a social economy model, a social movement model, a producers' model and an indigenous model. But in all cases, cooperatives were engulfed into state politics. However, little is known about the impact of liberalization measures on these models. Our research in 11 African countries reveals that cooperatives in Africa have survived the market forces and continued to grow in number and membership. We see a slow but sure erosion of the unified model and the adoption of a social economy model. Cooperatives in Africa are re-examining their organizational forms and diversifying their activities in response to members' interests and needs.
\end{abstract}




\section{Introduction}

Cooperatives have long been recognized to play important roles in society that translates into the improvement of living conditions of their members, particularly the low-income earning cadres of the population, as well as the society at large. Being voluntary, democratic and self-controlled business associations, cooperatives offer the institutional framework through which local communities gain control over the productive activities from which they derive their livelihoods (Ofeil, 2005: 14). Participating members tap the energies of group effort and economies of scale to engage in economic activities that they would not have otherwise been able to carry out on their own, thereby enhancing their chances of improving their living conditions. It is for this reason that cooperatives continue to be promoted in Africa and other parts of the developing world as some of the preferred instruments for poverty alleviation.

Cooperative development in Africa can generally be said to have traversed two main eras: the era of state control and that of liberalization. The first era that lasted up to the early 1990s saw the origin and substantial growth of cooperatives on the continent under state direction. Originating from government policy and directives rather than people's common interests and own motivation, these organizations were conditioned to emerge as dependent agents and/or clients of the state and other semi-public agencies in many countries, particularly the Anglophone ones. They hardly operated as private business enterprises that are primarily driven by the interests of their members and the demands of the market. By serving as instruments for implementing government socio-economic policies, cooperatives in many countries more or less served the interests of the state than the ordinary members and the general public. These institutions were subsequently engulfed into state politics to the extent that the failures of state policies found expression in the cooperative movement. This partly explains why reports on the failure of cooperatives, just like the state, to meet their developmental expectations during this era abound in the literature.

It is such failures that partly triggered calls for a change in cooperative development in the early 1990s, thereby setting in motion the second era. The authoritative World Bank studies on cooperatives (Hussi et al., 1993; Porvali, 1993), for example, acknowledged the potential role that cooperatives could play in the development process, but only if they were restructured and disentangled from the state so as to be run on business principles in line with the then evolving market economy. The implication, therefore, was that state control was stifling the performance of cooperatives and their potential contribution to development could only be realized if they operated according to market principles. With the liberalization of the economy in most African countries through the adoption of Structural Adjustment Programmes (SAPs) in the 1990s, cooperatives entered a new era as they were arguably afforded a beginning to run their affairs following the 'retrenchment' of the state from the development scene. Consistent with the new economic environment that was sweeping across Africa in the 1990s, many countries introduced new policies 
and legislations ostensibly to liberalize the cooperative sector. The main content of the resultant framework was to facilitate the creation of commercially autonomous and member-based cooperative organizations that would be democratically and professionally managed, self-controlled and self-reliant.

Whereas cooperative development in Africa during the first era is well documented in the existing literature, the second era of cooperative development has not been adequately researched. It is about a decade since the introduction of liberalization measures, yet very little is known about their impact on the development of cooperatives on the continent. It is surprising that very little literature on African cooperatives has been generated since the early 1990s despite the continuing debate in favour of cooperatives as the most suitable form of organization for alleviating poverty on the continent (Birchall, 2003; 2004). Besides the few studies in some countries that focus on disparate sectors of the cooperative movement like savings and credit (Evans, 2002; Petrie, 2002; Enarson and Wiren, 2005), agriculture (Aal, 1998; ICA, 2002; Milford, 2004; Myers, 2004; Tesfaye, 2005), dairy production (Staal et al., 1997; Owango et al., 1998) and management practices (Ofeil, 2005), one hardly comes across comprehensive accounts that inform the current status and functioning of the cooperative movement in any country on the continent since the liberalization of the economy. In the circumstances, a number of pertinent questions have remained unanswered since the mid 1990s. For instance, have cooperatives survived the fierce competition of the market or have they withered away? What has been the organizational response of cooperatives to the new economic environment that they suddenly plunged into? Are the cooperatives performing better than they did in the first era?

The purpose of this paper, therefore, is to respond to these questions by highlighting the impact of liberalization measures on the status, structural organization and performance of cooperatives in Africa. It is based on data that were collected from eleven African countries under the Essential Research for a Cooperative Facility for Africa study, which was initiated by the Cooperative Branch of the International Labour Office, funded by the UK Department for International Development (DfID) and coordinated by the Higher Institute for Labour Studies at the Katholieke University of Leuven, Belgium. It is argued in the paper that though the initial implementation of liberalization measures resulted into undesirable consequences for cooperatives in a number of countries largely due to the poor or inadequate preparation of the hitherto monopolistic organizations for the competitive market, liberalization has served well the interests of cooperative development on the continent. This is evidenced by the fact that those cooperative structures that have been redundant due to their inability to address the interests of the members are increasingly being abandoned and/or replaced by new ones while the old cooperatives that have adapted to the new environment have come out stronger than they were before the liberalization of the sector. To put these changes in perspective, it would be informative to sketch the organization and functioning of cooperatives before the introduction of liberalization measures. 


\section{The origin and arrest of cooperatives in Africa}

\subsection{The origin of cooperatives in Africa: an overview}

As it has already been alluded to, cooperative development in Africa did not originate from people's own interests and motivations. Their origin in most African countries can be traced to the colonial period when colonial governments directed the formation of these organizations for purposes of achieving, not the interests of the co-operators, but the interests of the said administration (Develtere, 1994). The main intention in establishing these organizations was to have instruments through which they would implement their socio-economic policies. For instance, the British, particularly in their settler colonies, wished to promote and protect the interests of white settler farmers in order to enhance their productivity so as to generate the very much needed income to run the affairs of the colonies and also export to Britain the cash crops that were required to fuel industrialization. Cooperative development, therefore, started among these white farmers as a means of improving their productivity and the initial legal framework that guided the formation of these organizations excluded African participation until after the Second World War when African nationalism gained momentum (Hyden, 1973). As exclusive enterprises of the white farmers and largely functioning under the whims of the colonial government that envisaged separate development in the colonies, cooperatives were then at variance with African interests.

On the other hand, the French wished to use cooperatives to implement their policy of 'assimilation' that sought to transform the African culture into a French one. Cooperatives were, therefore, viewed as modern institutions that would go a long way to civilize and modernize Africans. It was for this reason that the French imperial government passed a Decree on 29th June 1910 that prescribed the establishment of cooperatives, which were then known as provident societies, in French West Africa (Münkner, 1989). As modernizing institutions, cooperatives were to play various roles like keeping a stock of selected goods; supplying farm implements; processing agricultural produce; serving as insurance against disaster and accidents; granting loans; and improving production methods. To the extent that the 'modernization' that cooperatives were advancing clashed with the African culture that the people cherished and suffered during the colonial period for practising it, these organizations were serving the interests of the colonial administration more than that of the Africans.

In the Belgian territories, cooperative development was closely linked to the paternalistic approach of the colonial administration, which sought to keep Africans in relative underprivileged and subservient positions. In the 1920s, the colonial administration, out of its benevolence, had allowed Africans to form cooperatives to generate income for the established tribal administrative structures and produce additional benefits for the local population. But when the enterprises of these cooperatives developed to the point of competing with the private Belgian entrepreneurs in the 1940 s, the colonial administration quickly 
reviewed the policy on African cooperative development to restrict their activities to the social, educational and agricultural sectors as a way of protecting European interests. African cooperatives were henceforth strictly controlled by the colonial administration to the point of fixing the prices that cooperatives could pay their members for their agricultural produce, which was lower than what private entrepreneurs paid. The goal here was to undermine cooperative development among Africans. In the Portuguese territories, the story was not much different as agricultural cooperatives were merely functional appendages of rural extension work of semi-public agencies like the Coffee Institute of Angola or the Cotton Institute of Mozambique (Develtere, 2007).

These examples clearly show a disconnect between the original motivation to form cooperatives and the interests of the African people. The organizations were formed to meet external interests rather than the internal ones. The colonial powers were largely driven by the goal of maximizing benefits to the colonial state and the metropolitan economy by maintaining law and order as well as containing the local population. Cooperatives in this context were established as a government instrument for maintaining the existing socio-economic relations and only gradually introduce the natives to the extremely controlled export-oriented money economy that had been set up (Develtere, 1994: 48). By disregarding the existing traditional associations that existed in virtually all African countries, the colonial administrators reinforced the emerging cooperatives with new legal frameworks, promotional schemes and funding systems that would enhance their dependent development. Cooperative development was, therefore, directed from above by the colonial state in order to achieve its interests.

\subsection{African independence and the arrest of cooperatives}

This pattern of cooperative development was unfortunately retained at independence. However, different countries followed different paths, models or traditions that were largely determined by their colonial history. Develtere (2008) has described these models as the unified cooperative model, the social economy model, the social movement model, the producers' model and an indigenous model. Whereas the unified model, mainly found in the Anglophone countries, built up a single cooperative movement along a legal framework that provided for primary cooperatives at the bottom; secondary cooperatives in the form of unions and federations in the middle for the horizontal and vertical integration of the movement; and a single apex body at the top, the social economy model recognized cooperatives as just one of the many legal or institutional entities that brought together people sharing the same social and economic objectives. In this model, which was mainly found in the Francophone and Hispanic countries, it was the social and economic objectives that were shared by the parties involved; not the virtues of a cooperative model. Consequently, mutual societies, associations, foundations and trusts became part of the cooperative movement. 
The social movement tradition differed from both the unified and social economy models in that an interest group or established social organization such as a trade union, a women's association or a farmer's organization played the pivotal role in bringing members together to form a cooperative as an instrument, among many others, of collective action. The Belgian system of co-operation was very much embedded in this tradition and influenced cooperative thinking and practice in Central Africa. In contrast, the producers' tradition viewed cooperatives as economic vehicles for agricultural production. Thus, cooperatives were functional instruments of individual rural entrepreneurs and/or households that helped them to procure quality consumables and to market their produce. The economic role of the cooperative was primary and was considered to be a stepping stone towards achieving social objectives. This tradition was very well rooted in the Portuguese cooperative system and had inspired cooperative development in Lusophone countries in Africa. Finally, there was the indigenous cooperative tradition that was not introduced by the colonial powers. This was certainly the case in countries that were only to a limited extent exposed to colonialism such as Ethiopia, Sierra Leone, Liberia and Egypt. In these countries modern co-operatives were initiated by local agents who experimented with a blend of borrowed ideas and local adaptations to respond to socio-economic problems.

Though all these models or traditions were fundamentally different in their origin and orientation, the commonality is that they functioned under a legal framework that eventually enabled the state to intervene in cooperative affairs, thereby arresting cooperative development on the continent from the very beginning. This framework was established by independent African leaders on the conviction that cooperatives were important instruments for developing the new states that were characterized by socio-economic diversity and did not have adequate resources. For their alleged potential to mobilize local human resources to serve the entire nation and to transcend the existing class and/or ethnic divisions, cooperatives were promoted by governments as part of their populist-nationalist strategy for nationbuilding. With such confidence in the cooperative sector, governments created and strengthened the administrative apparatus responsible for cooperative development and adjusted their cooperative legislation to assign these organizations prominent roles in the development process. While in most cases the role of promotion, control and guidance of the sector was vested in special cooperative departments or ministries, the planning process and the financial participation of the state became a matter of general government policy (ibid.).

The evolving partnership between the state and cooperatives saw these organizations given special privileges and advantages that bordered on monopolistic positions in economic activities. For instance, in Kenya, Uganda and Tanzania, the governments set up Statutory Marketing Boards to manage the export of cash crops like coffee, cotton and pyrethrum, but cooperatives were made the sole agents of these Boards that could buy the produce from the farmers and process it for export. Though cooperatives received little from the Boards for their services, such a monopolistic position ensured their survival as it became the responsibility of the farmer to 
join the cooperatives if they were to sell their produce. Moreover, state-sponsored agricultural credit schemes were also administered through these cooperatives - yet another incentive for farmers to join cooperatives.

In some countries, governments shifted their initial policy on cooperative development from inducement to, more or less, coercion in order to speed up the development of the sector. Though cooperative development was supposed to be both voluntary and rapid, it was felt that running them on a voluntary basis was slowing down the pace; hence the compulsory option that would bring about rapid development. In this sense, the cooperative sector lost its voluntary character completely and strictly became subject to political and ideological imperatives. For instance, in Benin, Rural Renovation Cooperatives (coopératives d'aménagement rural) were established in 1961 by law and put under the tutelage of the state for the cultivation of food crops. The implementation of socialism in Tanzania saw the state take over sixteen cooperative unions and hundreds of societies in 1967. Membership to rural cooperatives was also made mandatory. In Haute Volta (now Burkina Faso), access to cultivable state land was reserved for those who accepted membership of a cooperative.

In addition, the involvement of the state in cooperative affairs saw these organizations also used as instruments for social and political control. Korovkin (1990) termed this as the political inclusion or co-optive encapsulation of the popular segments of society into state-controlled functional organizations. Thus, in many countries a number of strategic political measures were used to capture or arrest the cooperative movement: cooperative leaders were co-opted by the political system; the movement was used as a dispenser of patronage; competitive cooperative movements were not allowed; and cooperative apex bodies were not allowed or had to work in partnership with the authorities or the dominant party.

Though this partnership between the state and cooperatives resulted into tremendous growth of the sector in terms of membership and number of cooperatives, the movement lost its voluntary and bottom-up character that would have put the members in charge of their organizations. In their monopolistic position, cooperatives ceased to reach out to the members as it was up to the members to join the organizations. In return, member' morale to participate in the management of cooperatives declined, with some of them considering cooperatives not to be their organizations but part of the government. It, therefore, became necessary that the government enhances supervision over the activities of cooperatives if they were to be managed prudently.

Nevertheless, the rapid expansion of the sector far outstripped the capacity of government cooperative officers to manage the supervisory work. The then practice of cooperatives being guided by illiterate committee members did not help either. Supervision of technical operations was beyond their capabilities. Loss of capable African cooperative leaders and managers to the political arena worsened the situation. As Kabuga (2005) notes, 'every Tom, Dick and Harry of questionable 
motives, integrity and competencies who vied for cooperative leadership could invade the sector'. In that way, floodgates for nepotism, corruption, mismanagement and financial indiscipline were opened. In addition, farmers became increasingly sceptical when they realized that it was the state agencies and boards that set priorities and targets for their organizations rather than themselves; that extension work and animation rurale were meant to impose these conditions on them; and that - in the end - surpluses generated in the agricultural sector were ploughed into urban and industrial development projects. These factors were responsible for a rapid devaluation of cooperatives as a policy instrument for rural development. However, the essential development role assigned to the cooperatives rendered them too important to be allowed to die. Unfortunately, efforts to salvage them usually resulted in greater government control (Hussi et al., 1993).

Such control was enhanced by international donors to the cooperative movement who preferred to work through the government. Through the 1966 'Cooperatives (Developing Countries) Recommendation No. 127', the ILO called for governments to develop a comprehensive and planned cooperative development strategy in which one central body would be the instrument for implementing a policy of aid and encouragement to cooperatives. Subsequently, donors like the Nordic cooperative movements as well as the American and Canadian credit union movements linked up with African cooperatives through the governments of respective countries.

By the 1970s, it was already apparent that the arrest of cooperative development by the state was not translating into the expected social and economic changes. A study of cooperatives by the United Nations Research Institute for Social Development (UNRISD) found that the activities of cooperatives were irrelevant to the wider context of social and economic change. While the aims of agricultural cooperative policies were commonly directed towards self-reliance; agricultural innovation and increased productivity; social and economic equalization; and structural change, the UNRISD study found that cooperatives did little to contribute to the achievement of these objectives. In many cases, cooperatives reinforced existing patterns of exploitation and social stratification or introduced new forms of inequality. The poor had seldom been reached by the cooperative programmes under review; the position of women was negatively affected under the cooperative development process; and the means of production did not really come into the hands of co-operators. The general policies and the functioning of African cooperatives lay with government officials rather than with the formal leaders of the cooperatives. The researchers also concluded that in terms of agricultural innovation and increased productivity, no impressive achievements had been made. Rural cooperatives had much difficulty in tackling the problems of productivity and inequality simultaneously (Apthorpe 1970, 1972; Fals-Borda et al., 1976). The general policy conclusion of the UNRISD team was that one should question the wisdom of continuing along the dubious way so far taken, with its low probability of success and its waste of expectations, talents, resources and funds. 
Despite this critical revelation, there was little effort to change the approach to cooperative development in Africa. Though it attempted to portray cooperatives as voluntary organizations and to encourage 'spontaneous' participation in these organizations, the state continued to direct cooperative development. External development agencies in conjunction with governments continued to use cooperatives as mechanisms for implementing their projects and hardly viewed them as independent private enterprises with their own agenda and rationale (World Bank, 1986). Whereas cooperatives continued to serve donor organizations as instruments for channelling grants to recipients, they served governments by acting as collecting agents of agricultural produce for state marketing boards as well as distribution channels for agricultural inputs (Braverman et al., 1991).

As government agents, cooperatives were always subject to administratively imposed price controls to the extent that they could not realize sufficient returns or profits from their operations. Their activities and organizational structures were heavily regulated by laws that were too detailed to be understood by the average member, especially where there was no effort at cooperative education. In the context of their role as aid- or subsidy-lobbying organizations, cooperatives had their members and leaders develop a highly opportunistic, passive and instrumental attitude that compromised their financial contributions. Their share capital or membership fee payments were minimal or completely nonexistent. This led to undercapitalization of the cooperatives, with a dependence on external funding and the subsequent external accountability rather than internal accountability. Political patronage further eroded the autonomy and economic rationale of the cooperatives (Holmen, 1990). This, together with the profit constraints, led to widespread inefficiencies, mismanagement and irregularities in the sector.

By the end of the 1980s, cooperative development had been effectively arrested by the state in most African countries, such that these organizations could hardly survive without state and donor support. With the liberalization of the economy in the early 1990s, many observers and analysts feared that cooperatives would not withstand the market competition as then constituted (Hussi et al., 1993; Porvali, 1993; Birgegaard and Genberg, 1994). It is to the response of cooperatives to the new economic environment that we now turn.

\section{Liberalization and African cooperatives}

The triumph of neo-liberalism over communism that marked the end of the cold war at the close of the 1980s decade gave a clean bill of health to SAPs. Though some African leaders had resisted implementing them in the 1980s when they were introduced, such leaders could no longer hold on to their positions by the early 1990s. SAPs were essentially economic reform policies and measures that sought to rectify economic imbalances in African countries by reallocating responsibilities and resources in order to facilitate the emergence of a market-oriented economy. This was based on the neo-liberal assumption that development problems in Africa were due to the dominance of an inefficient state in the economy and an 
'underdeveloped' market, both of which had curtailed the freedom of the individual to realize his/her potential.

The programmes were, therefore, meant to retrench the state from the national economy and let the market allocate social and economic services. The policies and measures to this end included, among others, the privatization of public enterprises; removal of subsidies on the provision of public goods and services; liberalization of internal and external trade; free foreign exchange regimes that resulted in severe currency devaluation for purposes of promoting external trade; introduction of 'cost-sharing' for state supplied services; and restructuring government institutions, including retrenchment of staff in the public service (Bangura and Gibbon, 1992: 7). These measures necessitated several changes in the organization and operation of cooperatives.

In the first place, the state had to withdraw its traditional supportive role to the cooperatives in order to remain in tandem with the spirit of liberalization. Support services like audit, supervision and management training were the first to be withdrawn by the state in many countries, but without a replacement with an alternative institution that could perform the functions. Governments followed up this measure by cutting down the size of the cooperative development department that previously provided the withdrawn services (ICA, 1996). The expectation was that cooperatives would henceforth organize themselves for the provision of these services.

Second, in many countries, the state restructured the legal framework to give complete autonomy to cooperatives as a means of enabling them to fit in the emerging competitive market economy. This could only be done through legal reforms that promoted the development of co-operatives in tandem with the ICA co-operative principles of voluntary and open membership; democratic member control; member-economic participation; autonomy and independence; education, training and information; co-operation among co-operatives; and concern for community. It was envisaged that this would make the management of cooperatives democratic and professional, and thereby transform them from dependent organizations to selfcontrolled and self-reliant business associations capable of competing with other private enterprises on the market.

Third, the liberalization of the market attracted new actors in the economic sectors where cooperatives hitherto enjoyed monopoly status. The market now comprised of many sellers and buyers, who were guided, not by ownership, but by efficiency, competitive pricing and transparency. For instance, in the agricultural sector, the marketing transaction process radically changed. Previously, the ownership of the produce rested with the state marketing board, which then delegated the same to cooperatives. Thus, cooperatives could claim ownership of the produce until the point of export when ownership reverted back to the marketing board. But in the liberalized market system, the ownership of produce became rather disjointed. An individual farmer owned it up to the point he/she sold it to the next owner, who 
could be a private buyer or a cooperative society (ibid. 10). Cooperatives had, therefore, to compete with other players to buy and sell agricultural produce if they were to remain in business.

This new transaction process could have far reaching implications for the cooperatives. For instance, since membership in agricultural cooperatives was previously motivated by the desire to get access to the only marketing channel for produce, the availability of several market channels in the new era could significantly reduce cooperative membership as some members could opt to sell their produce to alternative buyers. Similarly, cooperative societies previously found it necessary to join cooperative unions in order to find a channel for primary processing and marketing of members' produce. With private buyers playing this role, societies could easily find no reason to belong to a union, especially a mismanaged and malfunctioning one. The ultimate end of such possibilities could go either way for cooperatives: failure to survive the competition or successful business organizations. How has this new environment worked for African cooperatives?

\subsection{Wither away African cooperatives?}

The point has already been made that by the time the cooperative movement was liberalized, most of the cooperatives in Africa were financially unstable while some had already become insolvent. Among the many problems that cooperatives faced included the persistence of their low business efficiency; weak capital base; heavy indebtedness and limited credit-worthiness; the weak entrepreneurial capability of managers and board members; and the unbalanced organizational structures of the movement (Birgegaard and Genberg, 1994). Some analysts maintained that these organizations had been ill-prepared to face the challenges of the liberalized economy, implying that their chance of survival in the new era were minimal and would probably wither away.

Evidence from the field suggests otherwise: cooperatives in Africa have survived the market forces and continued to grow in number and membership. Whereas the number of cooperatives in many countries is increasing, cooperative membership is no lower than it was a decade ago when liberalization measures were initiated. Table 1 illustrates this point by comparing data for 1992 and 2005 in four of the countries that were recently surveyed.

Table 1 - Number of cooperatives and members in selected countries, 1992 and 2005

\begin{tabular}{|l|c|c|c|c|}
\hline Country & \multicolumn{2}{c}{ Number of active coopertives } & \multicolumn{2}{c|}{ Coop members (in millions) } \\
& $\mathbf{1 9 9 2}$ & $\mathbf{2 0 0 5}$ & $\mathbf{1 9 9 2}$ & $\mathbf{2 0 0 5}$ \\
\hline Ghana & 1000 & 2850 & n.a. & 2.4 \\
\hline Kenya & 4000 & 7000 & 2.5 & 3.3 \\
\hline Nigeria & 29000 & 50000 & 2.6 & 4.3 \\
\hline Senegal & 2000 & 6000 & n.a. & 3.0 \\
\hline
\end{tabular}

Source: Porvali, 1993; Develtere et al., 2008. 
It is evident that the cooperative sector has continued to grow, at least in a number of countries, over the last decade. Even in countries where the cooperative movement was on the verge of collapse due to other factors like conflict, such as Rwanda and Uganda, the growth of cooperatives seem to be picking up. For instance, whereas there were only 554 cooperatives in Uganda in 1995 (ICA, 1996: 15), data from the Uganda Cooperative Alliance indicates that this figure had grown to 7,476 in 2005 (Develtere and Pollet, 2008). Though still recovering from the impact of the 1994 genocide that brought to a halt many economic activities, Rwanda was estimated to have 33,631 cooperative-type of organizations (Develtere and Pollet, 2008).

On the whole, we learn from survey data that there are some 150,000 collective socio-economic undertakings in the sampled countries that are considered to be co-operatives or co-operative types of business. This figure could be even higher if the semi-cooperative organizations in the Anglophone countries were also counted. For instance, the hundreds of burial societies and pre-cooperatives in South Africa are not included in this database. Nevertheless, this figure could also be much less if we subtracted the dormant ones. Estimates from Kenya, for instance, indicate that as many as 35 per cent of the registered cooperatives may be dormant. Thus, the figure that appears in Table 1 for Kenya is only for the active cooperatives; the dormant ones are estimated to be 3,640. A recent count in Uganda revealed that only 47 per cent of the registered societies could qualify as 'active'. It is, however, evident that there has been increased growth and presence of the cooperative movement in Africa over the last decade. The membership of these organizations has also witnessed marked growth. It is estimated that seven per cent of the African population reportedly belongs to a cooperative, with some countries like Egypt, Senegal, Ghana, Kenya and Rwanda reporting a higher penetration rate of over ten per cent.

A possible explanation for this trend in cooperative development in the new era is that liberalization seems to have facilitated the purification and revamping of the cooperative sector in many countries. Some old co-operatives have been revitalized to survive the liberalization process while the insolvent and non-competitive ones have been closed down. In addition, there is a proliferation of new co-operatives that are less dependent on state support as was the case in the past. Membership is now free and tries to keep pace with the demands of the market economy.

\subsection{The structural organization of cooperatives}

The ICA cooperative principle of 'co-operation among cooperatives' encourages vertical and horizontal networking of these organizations to enable them to extend to members services that single cooperatives may not otherwise be able to provide. The point has already been made that cooperative development in Africa was embedded in colonial-oriented traditions or models, which influenced the integration and structural organization of the cooperative movement on the continent. 
For instance, whereas the British-oriented unified model and the Portuguese-oriented producer model tended to emphasize vertical integration of cooperatives through their affiliation to state-imposed federative and apex organizations, the social economy and social movement models seemed to pay more attention to horizontal integration that allowed cooperatives some space to independently network with other organizations along similarity of interests and objectives. Consequently, in the era of state controlled cooperative development, there were wide variations in terms of vertical and horizontal integration of cooperatives in African countries depending on the respective traditions of the sector. Such variations had led some analysts to the conclusion that the cooperative movement in Africa was too fragmented to pass for a 'movement' (Develtere, 1994). Whereas some countries, particularly the Anglophone ones, had a structure that approximated a hierarchical form, replete with rules and regulations for interaction, others had very decentralized and fluid structures with minimal regulations.

The liberalization of the economy as well as the cooperative sector is increasingly witnessing a transformation in the structural organization of cooperatives on the continent, particularly in the Anglophone countries. Due to their inability to provide members with competitive services that the market demands, stateimposed federative and apex cooperative organizations are increasingly losing their members and, therefore, their significance in the liberalized economy. In Kenya, for instance, several secondary cooperatives suffer from severe inefficiency and mismanagement. This has resulted into, among other things, delays of payments to farmers for their produce. Cooperative societies and unions are increasingly finding no reason to retain their affiliation to these inefficient and mismanaged organizations (Wanyama, 2008). To make up for the services that they would have got from federative and apex organizations, cooperative societies are forming alternative voluntary trade- or activity-based unions and networks that are independent of the federative and apex organizations, where they exist, for service provision. Thus, bottom-up consensual networking and integration is taking place between cooperatives involved in similar trades or activities.

In the agricultural sector, for instance, this has led to the creation of some very viable unions and federations in some countries. In Rwanda, rice farmers recently formed the Rice Cooperative Union (UCORIRWA) to play the role of negotiating prices with the government. Though Ethiopia is yet to establish secondary and tertiary cooperative structures, which the government is working towards, coffee farmers in Oromiya have formed the Oromiya Coffee Producers Federation to represent their interests in the national and international marketing of the produce (Develtere and Pollet, 2008). A similar tendency is also apparent in the savings and credit cooperative sector. In Kenya, we have the examples of the Kenya Union of Savings and Credit Co-operatives (KUSCCO) and the Kenya Rural Savings and Credit Societies Union (KERUSSU) that have proved to be more active and efficient than the apex organization (Wanyama 2007). In Uganda, the Uganda Savings and Credit Cooperative Union (UCSCU) has its own national network of rural and urban savings and credit cooperative societies (ICA, 1996). 
This tendency is clearly leading to the slow, but sure erosion of the unified model of cooperative development where it existed in Africa. This model's archetypal top-down structure (of apex organization - federations - unions - societies) no longer functions coherently. In Uganda, for example, cooperative unions are characterized by more disintegration than cooperative unity as their members (cooperative societies) increasingly view them as 'dead institutions and are happy with liberalization because it has offered them better marketing channels as well as absorbing poor quality produce traditionally rejected by cooperative unions' (ICA, 1996: 14). Since cooperative societies are affiliated to the national federations and the apex Uganda Cooperative Alliance through their cooperative unions, the loss of membership by the unions has similar implications for the rest of the higher level cooperative organizations and, most importantly, a large section of the cooperative sector continues to operate outside the unified model. The same situation has already been noted in Kenya.

In other countries, the erosion of the unified model has been aggravated by the collapse of the apex and secondary cooperatives. In Ghana and Nigeria, for example, apex and secondary cooperatives (though economically viable) have been 'hijacked' and staffed by the government (Tsekpo, 2008; Enete, 2008). The South African cooperative sector has a rather fragmented image, with an apex body called the National Cooperative Association of South Africa (NCASA) to which both secondary and primary societies can affiliate. Many cooperatives, however - and this presumably applies to a good part of Sub-Sahara Africa - rise and fall without ever belonging to a secondary or tertiary structure. The sector's vertical integration was recently dealt a major blow following the disintegration of NCASA (Theron, 2008).

The unified model is further fading away following the recent tendency towards organizing cooperatives along other economically active group-based organizations that emphasize associational life. Unlike in the past where co-operators largely coalesced around economic motives, cooperatives are increasingly trying to incorporate social values as well. Members tend to have a group identity and participate in the associative life of the cooperative as envisaged in the holistic social economy model. It is increasingly being accepted that the homogeneity of interests is crucial for business operations in cooperatives because it enhances contacts and interactions between and among members, directors and the management, which, in turn, enhances loyalty and trust. Consequently, some of the cooperatives invest a lot in horizontal member interaction and give members some extra value that makes them loyal to the organization. The Menshat Kasseb Cooperative in Giza, Egypt, for example, does not only process and market the members' farm produce. It also provides training courses, home economics lessons to female members, health care and special assistance to small and poor farmers (e.g. subsidized shipping of produce to markets). Thus, the emerging cooperatives are inclined towards defending the individual and collective interests of the community they represent like other social economy organizations tend to do (Defourny et al., 2001). 
On the whole, the indication is that liberalization has given cooperatives the impetus to re-examine their organizational formations with a view to reorganizing in their best interest rather than the interest of the state as had been the case in the past era. Nevertheless, it is also apparent that it is only 'the fit' cooperatives that are surviving this liberalization wave as has already been alluded to and will be shown shortly.

\subsection{The diversification of cooperative ventures}

For the better part of the history of cooperative development on the continent, agriculture and credit were the 'traditional' sectors of cooperative ventures in many African countries, with the latter mainly serving as a complement to the former. This arrangement saw the proliferation and predominance of agricultural cooperatives, many of which were unifunctional in nature (thus, organized around a single activity) despite the fact that some of them called themselves 'multipurpose cooperatives'. This pattern of unifunctional cooperatives was in tandem with the monopolistic status that the state had afforded these organizations. Certain cooperatives dominated the handling of specific agricultural produce like coffee, cotton, cocoa, pyrethrum, dairy, etc.

Nevertheless, the loss of the monopoly status, coupled with the business-oriented demands of the market, is increasingly seeing cooperatives redesign their activities competitively. For instance, though agricultural activities remain predominant in the cooperative ventures of most countries, those that are no longer profitable (like cotton and pyrethrum in Kenya) are increasingly being abandoned in favour of others (like dairy and savings and credit in the same country) that are more viable on the market. This move towards the diversification of ventures partly explains, for example, why the continent is witnessing substantial growth of cooperatives in the financial sector. In many countries (Kenya, Nigeria, Niger, Rwanda, Cape Verde) saving and credit cooperatives (SACCOs) are the second largest cooperative sector, while in some countries (like Kenya) they are financially the strongest. For example, Harambee Savings and Credit Cooperative Society in Kenya has over 84,000 members, employs 235 staff and had a turnover of over 500,000,000 Kenya Shillings (about US\$7,100,000) in 2005. In the same country, Mwalimu SACCO presented an even better financial performance in the year under review. With fewer members $(44,400)$, it had a turnover of over 700,000,000 Kenya Shillings (about US $\$ 10,000,000)$. The vibrancy of SACCOs is further illustrated by the fact that they have replaced agricultural marketing co-operatives as the leading shareholders, due to their financial strength, in the Co-operative Bank of Kenya - the fourth largest bank in Kenya that is owned by the cooperative movement (Wanyama, 2008).

In Senegal over half a million people belong to one of the three largest savings and credit movements (Develtere and Pollet, 2008). In Rwanda, 398,799 persons or 12 per cent of the adult population are affiliated to one of the savings and credit co-operative societies affiliated to the Union of People's Banks (Union des Banques Populaires). In 2004, their collective savings totaled some 44 million 
US dollars (Nyamwasa, 2008). In the same year, the 250 member societies of the Ghana Cooperative Credit Unions Association served over 156,000 cooperative shareholders, who had deposits of over 314 billion Cedis (about US\$34,696,133) and benefited from some 262 billion Cedis (about US\$28,950,276) in loans (Tsekpo, 2008).

There are at least three main reasons behind the emerging success of the savings and credit cooperatives in Africa. First, they largely rely on their own financial resources to transact their activities; thereby avoiding the pitfall of dependency. Second, being in the financial sector, their services will always remain on demand unlike agricultural co-operatives that are dependent on the performance of the agricultural sector. Thus, their activities are in tandem with the new market economy and they tend to respond to the ever imminent need for access to capital by the poorer segments of society on the continent. Zeller (2003: 21) arrived at a similar conclusion and contended that the major comparative advantages of SACCOs or credit unions lie in their ability to service large numbers of depositors, and use these savings to provide a diversified range of loans to individual members. The third key strength is their ability to reach out to people who would otherwise remain excluded from the financial markets. Zeller (ibid.) concluded that while most members of credit unions are non-poor, they also reach many poor people because of their breadth of outreach.

Besides savings and credit, cooperatives are also increasingly venturing into other 'non-traditional' sectors like housing, consumer, cottage industry and distilleries. In Senegal, for example, housing cooperatives are increasingly becoming strategic organizations for marginalized migrants in the suburban periphery of Dakar (Fall, 2008). Housing cooperatives have also a marked presence in northern and eastern Africa following the influx of people from the rural areas into the big cities in search of employment opportunities. For instance, Ethiopia alone has up to 3,400 housing cooperatives (Lemma, 2007) while Egypt has almost 2,000 housing cooperative societies with a membership of two million (Aal, 2008). The presence of consumer cooperatives is also increasing. In Cape Verde, two thirds of the country's cooperative sector consists of consumer cooperatives (Mendonca 2007). In Egypt, this sector is equally growing very fast, with a consumer cooperatives federation reporting the ownership of 4,320 consumer shops (Aal, 2008). A more recent development is the growing number of handicraft, cottage industry and other small productive cooperatives like distilleries in some countries like Ethiopia, Ghana, Kenya and Egypt.

Furthermore, some cooperatives are steadily shifting from being unifunctional to multifunctional by taking on other activities as demanded by the members as well as the market forces. For instance, hitherto agricultural cooperatives are diversifying their activities by also venturing in the fields of savings and credit as is the case in Ghana, Egypt and Kenya. To this end, cooperative ventures in Africa are increasingly becoming market-driven and responsive to changing circumstances. More than ever before, cooperatives are invariably functioning as demand-driven and market- 
oriented businesses. They continue to seek market niches and marketable products; invest in quality management; and their pricing as well as interest rate policies are increasingly being inspired by the prevailing market conditions rather than state policy as was the case in the past. Some of them are now hiring professional staff and have put in place personnel retention policies to strengthen a management system that can face the challenges of a competitive market. It is in this regard that both management and members are now increasingly showing preference for a growth oriented approach in terms of asset base, business turn-over, market share and profitability (Yeboah, 2005; Tesfaye, 2005).

\subsection{Sifting the grain from the chaff: the performance of cooperatives}

As it has already been alluded to, the liberalization of the economy and the cooperative sector in Africa was not linear; neither did it produce similar results across countries or even within countries. The immediate impact in most countries was generally negative. For instance, in Cape Verde where the state had previously proclaimed solemnly the cooperative mode of production in the constitution and subsequently controlled these organizations with a Marxist zeal, the abrupt withdrawal of the state from cooperative affairs in the 1990s left the sector in disarray. The number of cooperatives and their membership suddenly plummeted. Without proper cooperative legislation and state support, the Foro Cooperativo, a non-governmental coalition of cooperatives, is trying to revamp the movement but with a lot of difficulties (Mendonça, 2008).

In Uganda, a similar pattern was observed in the early 1990s. The retreat of the state and the emergence of private entrepreneurs, particularly in the marketing of agricultural produce, led to the collapse of many cooperative societies and unions. With private buyers of agricultural produce offering better prices and paying farmers promptly for their produce, member commitment, participation and loyalty to their cooperatives drastically declined. Since they were receiving little incentive in the form of farm inputs, agricultural credit and bonuses from the cooperatives, all that such members were looking for was a buyer for their produce at competitive prices; which the private entrepreneurs were offering relative to the bureaucratic, inefficient and at times costly cooperatives (ICA, 1996: 11-14). The end result is that members ceased to market their produce through cooperative societies. On the other hand, the cooperative societies that managed to retain their members by offering better services found cooperative unions exploitative, for the unions paid them lower commissions that were inadequate to cover the operational costs of the services that they rendered. Thus, the societies were also at liberty to sell the produce to any willing buyer on the market, with the result that they stopped doing business with the unions. In the circumstances, cooperative societies and unions could not help, but collapse. The sector is just reorganizing itself to 'start again' and there is evidence of better performance than was the case in the mid 1990s (Mrema, 2008). 
In other countries, like Ghana and Kenya, governments had to step-in to re-orient cooperatives to work in a liberalized environment in order to prevent the possible collapse of some cooperatives. It should, however, be emphasized that such negative consequences seem to have occurred not primarily because liberalization is bad for cooperatives, but largely due to the poor or lack of adequate preparation of the sector, which had been handed a monopoly status by the state over the years, for the challenging competition in the market economy. This is evidenced by the fact that those cooperatives that have adapted to the new environment have come out stronger than they were before the liberalization of the sector. We have already made reference to successful SACCOs in Kenya, Rwanda, Nigeria and Niger. Some more examples may help to send this point home.

Githunguri Dairy Farmers Co-operative Society in Kenya is one of the prime cases in this regard. Formed in 1961 through state initiative, it membership now stands at 12,000 from the initial 31. The collapse of the Kenya Co-operative Creameries (KCC), the umbrella cooperative union in the dairy sector, in the early 1990s severely affected the society's initial activity of collecting milk from members for sale since it did not have a milk processing plant. The liberalization of the cooperative movement in 1997 helped to turn the fortunes of the society for at least three reasons. First, liberalization afforded the management committee of the society the freedom and power to hire professional staff to steer the day-today management activities of the co-operative. This was possible because the committee, which took office in 1999, had a visionary leadership that took the opportunity to run the cooperative without pressure from the state and in the interest of the society's members. Second, the well-focused committee also used the new power to borrow and charge the society's property to get a loan of about 70 million Kenya shillings (about US\$1 million) from oikocredit of the Netherlands to put up a dairy processing plant, which could not have been easily done under the previous state control. The desire to build the plant had previously been frustrated by the lack of funds in the midst of state-imposed regulations that did not allow cooperatives to borrow from outside the cooperative movement against their assets. Third, the society got the freedom to sell its produce to any willing buyer on the market; a radical departure from the past when it was only allowed to sell milk to the ailing KCC. Located on the outskirts of Nairobi, the society found a ready market for its products in the city.

The society's activity of marketing members' milk has blossomed since the completion of its own modern milk processing plant in 2004. It collects and processes about 80,000 litres of milk daily, up from about 25,000 litres in 1999 before the construction of its plant. It has eighteen vehicles for transporting milk from 41 collection centres across Githunguri division of Kiambu district, its area of operation. The plant processes four main branded products, namely packed fresh milk; yoghurt; ghee; and butter. Besides this activity, the co-operative also supports its members to improve productivity through services like artificial insemination; extension; and animal feeds that are stocked in its 31 stores that straddle its area of operation. These services are availed to members mainly on credit that is recovered 
from the sale of their milk. These activities have seen a tremendous improvement in milk production by members, to which the co-operative has responded by offering competitive prices and promptly paying for members' produce. Some of the members who had become dormant before the construction of the plant had reportedly revived dairy farming. The turnover of the co-operative in 2005 was over one billion Kenya shillings (US\$14,285,714), with a share capital of over 100 million Kenya shillings (US\$1,428,571).

The expansive activities of the co-operative are taken care of by a staff of about 300 employees that are recruited on the basis of an employment policy. Whereas the lower cadre staff is recruited from within Githunguri division, management staff is sought nationally and appointed competitively on the basis of professional qualifications. It is significant that unionizable employees have formed a trade union, which has entered a collective bargaining agreement (CBA) with the co-operative. This is increasingly enabling the co-operative to attract and retain competent staff relative to the era of state control when there was no employment policy but the discretion of the Commissioner of Co-operative Development (Wanyama, 2008).

The case of Kuapa Kokoo Limited in Ghana also provides a compelling argument in favour of the fortunes of liberalization for cooperative development. Having witnessed the decline of the cooperative sector under state control, the pioneers capitalized on the opportunities that were created following the liberalization of internal marketing of cocoa in the country to set up a market-oriented cooperative organization. In order to take maximum advantage of the new economic environment, Kuapa Kokoo, which was started in 1993 as a limited liability company using a cooperative model, was transformed into an organization best characterized as a mix of a cooperative, a limited liability company and a trust. With a membership of 45,000 spread across 1,650 village societies, it functions as a multipurpose cooperative union comprising of (a) a farmers' union - a production cooperative; (b) Kuapa Kokoo Ltd. - a farmer owned private licensed cocoa buying company that serves as the commercial and trading wing of the farmers' union; (c) Kuapa Kokoo Farmers' Trust - a trust company for managing premiums from sales of cocoa to companies abroad through fair trade; (d) Kuapa Kokoo Credit Union - a SACCO promoting savings and making credit easily accessible to members; and (e) Day Chocolate Company - a chocolate manufacturing wing of the organization. The organization has a three-tier structure of elected officials at the village society, area council and national executive council that oversee its management. Seven members of the cooperative are elected as officers at the village society level and they in turn elect three of their number to the area council. In 2006, there were about 28 area councils. Each area council elects one member to the national executive council. The national executive council then elects four of its members to the board of Kuapa Kokoo Limited and another four to Kuapa Kokoo Farmers Trust. Whereas these elected officials deal with the policy issues in the management of the organization, the day-to-day administration is the responsibility of employed professional management staff. The organization had 261 employees in 2006. 
This sophisticated cooperative organization provides a useful model for production and marketing cooperatives. A combination of its activities has seen the cooperative sell 38,000 tons of cocoa per year. The credit union attached to the cooperative gives financial power to members to secure inputs and also take care of their social needs when they need extra finances, thereby avoiding the expensive financial intermediaries. Furthermore, continuous education by the Research and Development Department of Kuapa Kokoo has aided primary societies to consistently improve the living conditions of farmers. In addition to engendering high bonding and solidarity among cooperative members, the village societies also provide community service in the form of potable water and school blocks (Tsekpo, 2008). A combination of these services could not be provided by a single cooperative in the era of state control.

Indeed, it may be no exaggeration to say that in virtually all African countries, one comes across a number of successful cooperative ventures that are doing better in the liberalized environment than they did under state control. For instance, in Ethiopia, Oromia Coffee Farmers' Cooperative Union has improved on its coffee marketing, particularly in the export sector, during this era. With a membership of 74,725 coffee farmers and twenty employed staff, it has opened coffee shops in Europe and the USA, which has seen it sell 2,691 tons of coffee annually and record an average annual turnover of 8 million US dollars (Lemma, 2007). Though the cooperative movement in Cape Verde is just picking up the pieces after the abrupt withdrawal of the state from their affairs, there is the unique example of UNICOP de Fogo, a consumer cooperative. With a membership of 404 and employing 58 staff, it pools an annual turnover of 2.8 million US dollars and is increasingly becoming instrumental in the provision of loans and assisting members cope with funeral expenses (Mendonça, 2008).

In Egypt, the General Cooperative for Weaving and Spinning Workers, a consumer cooperative, has 38,950 members; employs 900 staff; and records an annual turnover of 69.2 million Egyptian pounds (over US\$12 million) (Aal, 2008). In Rwanda, the Union des Banques Populaires, a savings and Credit federation, has a huge membership totalling 398,799 and employs 600 members of staff. It has accumulated US\$44 million in savings; it has expended US\$36 million in loans; and makes an average annual profit of US\$1.5 million. The union is increasingly becoming instrumental in the provision of risk coverage to savings and credit societies in the country, thereby strengthening their capacity to serve a larger clientele (Nyamwasa, 2008).

In South Africa, the story of a small tea marketing cooperative is really fascinating. Fourteen smallholder rooibos tea farmers decided to form the Rooibos Tea Cooperative in 2001 in order to establish a facility to process each member's tea before it could be delivered to a marketing company to which some of the small farmers were contractually bound to deliver all their produce. However, there was unhappiness with the price it paid that the cooperative opted to get a much better price by marketing their tea through an agent, under a fair trade label and as 
organically produced. During the first year of its operation the cooperative leased a centrally located facility to produce the tea and marketed it through the agent. So successful was this that the following year all the members were marketing their tea through the cooperative, and the cooperative realized a substantial surplus. The 100 South African rands (US\$15.6) entrance fee contributed by each of the fourteen members gave an initial capital of 1,400 rands (US\$222.2) in 2001. At the end of 2004, its membership had increased to only 36, but the cooperative had a turnover of 1.25 million rands (US\$198,412.7) and assets worth 896,708 rands (US\$142,334.6), including a truck to deliver the tea, a welding machine and a tractor used in the production of tea.

The list of successful examples of cooperatives in the liberal era can be long, just as the list of unsuccessful ones may as well be. What is certainly emerging from the field is that the liberalization of the economy and the cooperative sector is steadily offering some cooperatives the opportunity to reinvent their business ideals. The available data, nevertheless, suggests that more of such opportunities are increasingly being utilized by the well-organized cooperatives that have committed leadership and a clear vision of finding solutions to the daily problems of their members. This is conditioning such cooperatives to function as demand-driven and market-oriented business organizations, thereby remaining in tandem with the forces of liberalization. On the other hand, cooperatives that are not organized along these lines are losing their members due to their inability to provide the demanded services and subsequently closing down. It seems that liberalization has produced a sieve for sifting the grain from the chaff in the cooperative sector. Since the chaff rotes as the grain grows, the future for African cooperatives in a liberalized economic environment is getting brighter.

\section{Conclusion}

It has been the purpose in this discussion to highlight the impact of liberalization measures on the status, structural organization and performance of cooperatives in Africa. Evidence from the field suggests that cooperatives in Africa have survived the market forces and continued to grow in number and membership. Whereas the number of cooperatives in many countries is increasing, cooperative membership is no lower than it was a decade ago when liberalization measures were initiated. The market forces have, however, triggered a transformation in the structural organization of cooperatives on the continent, particularly in the Anglophone countries. Due to their inability to provide members with competitive services that the market demands, state-imposed federative and apex cooperative organizations are increasingly fading away. To reclaim the services that were previously provided by such federative and apex organizations, cooperative societies are forming alternative independent voluntary trade- or activity-based unions and networks through a bottom-up consensual networking and integration process. This tendency is clearly leading to the slow, but sure erosion of the unified model of cooperative development, where it existed, and the adoption of the social economy model. Thus, the indication is that liberalization has given cooperatives the impetus to re- 
examine their organizational formations with a view to reorganizing in their best interest rather than the interest of the state as had been the case in the past era. It is in this regard that cooperatives are increasingly diversifying their activities in order to respond to the challenges of the market as they endeavour to satisfy the interests and demands of their members. Those cooperatives that have managed to adapt to the new market system, the number of which continue to increase in many countries, are recording better performance than they did in the past era of state control. Such cooperatives seem to have reinvented the business wheel that they had lost in the past era when they were prematurely arrested by the state. Whereas the future of cooperative development in a liberalized economic environment seems to be bright, the challenge is how to inculcate the business virtues in the less-adapted cooperatives in order to spread the benefits of the 'new' mode of cooperation to a wider population on the continent. 


\section{List of references}

AAL Mohamed H. A., 1998, 'Farmers and cooperatives in the era of structural adjustment', in Nicholas S. Hopkins Kirsten Westergaard, eds., Directions of Change in Rural Egypt, The American University in Cairo Press, Cairo.

AAL Mohamed H. A., 2008, 'The Egyptian cooperative movement: between state and market', in P. Develtere, I. Pollet F. Wanyama, eds., Cooperating Out of Poverty: The Renaissance of the African Cooperative Movement, ILO/The World Bank Institute, Geneva/Washington D.C.

APTHORPE R., 1970, Rural Cooperatives and Planned Change in Africa: Case Materials, UNRISD, Geneva.

APTHORPE R., 1972, Rural Cooperatives and Planned Change in Africa: An Analytical Overview, UNRISD, Geneva.

BANGURA Y. P., 1992, 'Adjustment, authoritarianism and democracy' in P. Gibbon, Y. Bangura A. Ofstad, eds., Authoritarianism, Democracy and Adjustment, The Scandinavian Institute of African Studies, Uppsala.

BIRCHALL J., 2004, Co-operatives and the Millennium Development Goals, ILO, Geneva.

BIRCHALL J., 2003, Rediscovering the Co-operative Advantage: Poverty Reduction through Self-help, ILO, Geneva.

BIRGEGAARD L. GENBERG B., 1994, Cooperative Adjustment in a Changing Environment in Africa, International Cooperative Alliance, Geneva.

BRAVERMAN A. et al., 1991, Promoting Rural Cooperatives in Developing Countries - The Case of Sub-Saharan Africa, World Bank Discussion Papers No. 121, The World Bank, Washington D.C.

DEFOURNY J., DEVELTERE P. FONTENEAU B., 2001, The Social Economy: North and South, HIVA/CES, Leuven/Liege.

DEVELTERE P., POLLET I. WANYAMA F., eds, 2008, Cooperating out of Poverty: the Renaissance of the African Cooperative Movement, ILO/The World Bank Institute, Geneva.

DEVELTERE P., 2008, 'Cooperative development in Africa up to the 1990s', in P. Develtere, I. Pollet F. Wanyama, eds., Cooperating Out of Poverty: The Renaissance of the African Cooperative Movement, ILO, Geneva.

DEVELTERE P. POLLET I., 2007, 'Renaissance of African cooperatives in the 
21st century: lessons from the field', in Develtere et al., eds, Cooperating out of Poverty: the Renaissance of the African Cooperative Movement, ILO/The World Bank Institute, Geneva.

DEVELTERE P., 1994, Co-operation and Development, ACCO, Leuven.

ENARSON S. WIREN K., 2005, Malawi Union of Savings and Credit Cooperatives, CGAP Working Group on Micro Insurance: Good and Bad Practices, Case Study No. 8.

ENETE A., 2008, 'Political and genuine cooperatives in Enugu State - Nigeria', in Develtere et al., Cooperating Out of Poverty, op, cit.

EVANS A. C., 2002, The Unpaved Road Ahead: HIV /AIDS \& Microfinance: An Exploration of Kenya Credit Unions, SACCOs , Research Monograph Series No. 21, World Council of Credit Unions, Madison, Wisconsin.

FALL A. S., 2008, 'The Senegalese cooperative movement: embedded in social economy', in Develtere et al., eds., Cooperating Out of Poverty, op. cit.

FALS-BORDA O., APTHORPE R. INAYATULLAH, 1976, 'The crisis of rural cooperatives: problems in Africa, Asia and Latin America', in J. Nash, J. Dandler N. S. Hopkins, eds., Popular Participation in Social Change , Mounton Publishers, The Hague/Paris.

HOLMEN H., 1990, State, Cooperatives and Development in Africa, The Scandinavian Institute of African Studies, Uppsala.

HUSSI P., MURPHY J., LINDBERG O. BRENNEMAN L., 1993, The Development of Co-operatives and Other Rural Organizations: the Role of the World Bank, The World Bank, Washington, D.C.

HYDEN G., 1973, Efficiency versus Distribution in East African Cooperatives: A Study in Organizational Conflicts, East African Literature Bureau, Nairobi.

INTERNATIONAL CO-OPERATIVE ALLIANCE, ICA, 2002, Status of Agricultural Marketing Co-operatives in Kenya, ICA-ROECSA, Nairobi.

INTERNATIONAL CO-OPERATIVE ALLIANCE, ICA, 1996, Restructuring of the Cooperative Movement in Uganda, ICA Regional Office for East, Central \& Southern Africa, Kampala.

KABUGA C., 2005, 'Cooperative traditions in Anglophone countries', Report in Essential Research for a Cooperative Facility for Africa, ILO, Geneva, mimeo. 
KOROVKIN T., 1990, Politics of Agricultural Cooperatives: Peru, 1969-1983, University of British Columbia Press, Vancouver.

LEMMA T., 2008, 'Growth without structures: the cooperative movement in Ethiopia', in Develtere et al., eds., Cooperating Out of Poverty, op. cit.

MENDONCA J. G., 2008, 'Surviving on the islands: cooperatives in Cape Verde', in Develtere et al., eds., Cooperating Out of Poverty, op. cit.

MILFORD A., 2004, Coffee, Cooperatives and Competition: The Impact of Fair Trade, Chr. Michelsen Institute, Bergen.

MREMA H. A., 2008, 'Uganda: starting all over again', in Develtere et al., eds., Cooperating Out of Poverty, op. cit.

MUNKNER H. H., ed., 1989, Comparative Study of Co-operative Law in Africa, Marburg Consult, Marburg.

MYERS A., 2004, Old Concepts Revisited: Are Cooperatives the Way Forward for Smallholder Farmers to Engage in International Trade? London School of Economics \& Political Science, London.

NYAMWASA J. D., 2008, 'Jump-starting the Rwandan Cooperative Movement', in Develtere et al, Cooperating Out of Poverty, op. cit.

PETRIE R., 2002, Rwanda Credit Unions Member and Non-member Survey 2002, WOCCU, Madison, Wisconsin.

PORVALI H., ed., 1993, The Development of Co-operatives, Agriculture and Rural Development Series No. 8, The World Bank, Washington, D.C.

OFEIL K. A., 2005, 'Participative schemes and management structures of Ghanaian cooperatives', Journal of Co-operative Studies , Vol. 38:3, No. 115, pp. 1426.

OWANGO M., LUKUYU B., STAAL S. J., KENYANJUI M., NJUBI D. THORPE W., 1998, 'Dairy co-operatives and policy reform in Kenya: effects of livestock service and milk market liberalization', Food Policy, Vol. 23, No. 2, pp. 173-185.

STAAL S., DELGADO C. NICHOLSON C., 1997, 'Smallholder dairying under transactions cost in East Africa', World Development, Vol. 25, No. 5, pp. 779-794.

TESFAYE A., 2005, Revitalizing Market-Oriented Agricultural Cooperatives in Ethiopia, ACDI-VOCA, Addis Ababa. 
THERON J., 2008, 'Cooperatives in South Africa: a movement, re-emerging', in Develtere et al., Cooperating Out of Poverty, op. cit.

TSEKPO A. K., 2008, 'The cooperative sector in Ghana: small and big business', in Develtere et al, Cooperating Out of Poverty, op. cit.

WANYAMA F. O., 2008, 'The qualitative and quantitative growth of the cooperative movement in Kenya', in Develtere et al, Cooperating Out of Poverty, op. cit.

WORLD BANK, 1986, Rural Cooperatives in World Bank Assisted Projects and some Related Development Issues, The World Bank, Washington D.C.

YEBOAH G., 2005, 'The Farmapine model: a cooperative marketing strategy and a market-based development approach in Sub-Saharan Africa', Choices: The Magazine of Food, Farm and Resource Issues , Vol. 20, No. 1, pp. 81-85. Available from: http://www.choicesmagazine.org

ZELLER M, 2003, Models of Rural Financial Institutions, Institute of Rural Development, Georg-August University, Göttingen. 




\section{Coop $^{\text {afrlca }}$ Working Paper No.1}

\section{Reinventing the wheel? African \\ cooperatives in a liberalized economic \\ environment}

Fredrick O. Wanyama, Patrick Develtere and Ignace Pollet

*This article was published in the Annals of Public and Cooperative Economics, Volume 80 Issue 3 (September 2009)

Cooperative development in Africa can be said to have traversed two main eras: the era of state control and that of liberalization. The first era lasted up to the early 1990 s and saw the origin and substantial growth of cooperatives on the continent. During that period, different models of cooperative development were introduced on the continent. We distinguish a unified cooperative model, a social economy model, a social movement model, a producers' model and an indigenous model. But in all cases, cooperatives were engulfed into state politics. However, little is known about the impact of liberalization measures on these models. Our research in 11 African countries reveals that cooperatives in Africa have survived the market forces and continued to grow in number and membership. We see a slow but sure erosion of the unified model and the adoption of a social economy model. Cooperatives in Africa are re-examining their organizational forms and diversifying their activities in response to members' interests and needs.

ILO Office for Kenya, Somalia,

Tanzania and Uganda Coop ${ }^{\text {AFRICA }}$

Kazi House, Maktaba Street

P.O. Box 9212

Dar es Salaam

United Republic of Tanzania

Tel: +255.22 .2196700$

Fax: +255.22 .2122597$

E-mail: coopafrica@ilo.org

www.ilo.org/coopafrica

International Labour Office

Cooperative Programme (EMP/COOP)

4 , route des Morillons

1211 Geneva 22

Switzerland

Tel: + 41.22.7997021

Fax: +41.22 .7996570$

E-mail: coop@ilo.org

www.ilo.org/coop

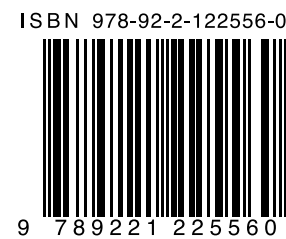

